\title{
COMMENTS
}

\section{Application of the Federal Securities Laws to Noncontributory, Defined Benefit Pension Plans}

Since 1875, when the American Express Company first established a plan for providing retirement benefits to disabled, elderly workers, ${ }^{1}$ an increasing number of employers in the United States have resorted to the use of private pension plans to provide additional benefits for their employees. ${ }^{2}$ The majority of these pension plans are "noncontributory" plans, financed entirely by the employer or the organization sponsoring the plan. ${ }^{3}$ Furthermore, the vast majority are "defined benefit" plans, under which the retirement benefits to be received by the employee are fixed, and the employer's contribution to the pension fund is adjusted to whatever level is necessary to provide those benefits. ${ }^{4}$

The astonishing increase in the size and number of private

I See 1 M. Latimer, Industrial Pension Systems in the United States and Canada 20 21 (1932). See also W. Greenough \& F. King, Pension Plans and Public Policy 27 (1976).

2 See N. Ture, The Future of Private Pension Plans 1, 13-58 (1976): "In 1940, 4.1 million employees . . . participated in private pension plans; in 1973, the number had increased more than eightfold to 33.1 million employees." Id. at 1.

${ }^{3}$ Seventy-seven percent of the pension plans originating in the period from 1875 to 1929 , and still operating in 1929, were noncontributory. Moreover, these noncontributory plans covered over 95 percent of all pension plan participants. $1 \mathrm{M}$. LATIMER, supra note 1 , at 31 .

One commentator has suggested that the majority of early pension plans were noncontributory because such plans offered "the advantages, at least in the opinion of the managements, of not complicating relations with trade unions, retaining full control of retirements and final judgment on the fulfillment of qualifications, discouraging strikes, and permitting retirement for the good of the service and the public safety." Id. at 44 . A recent study has found that more than 75 percent of all pension plans are financed entirely by employer contributions. U.S. Dep't of Labor, Characteristics of 178,670 Plans on File January 1, 1973 , at 5 (1973). The predominance of noncontributory plans today is undoubtedly explained by the favorable tax treatment accorded "qualified" pension plans. See I.R.C. $\$ 404$. See also Treas. Reg. $\$ 1.402(a)-1(a)(1)(i)$, T.D. $6887,1966-2$ C.B. 129.

4 This comment will deal only with defined benefit plans since they comprise about $90 \%$ of all pension plans. See Study Group of 1933 Act-General Subcommittee on Daniel, et al. v. International Brotherhood of Teamsters, A Report to the Committee on Federal Regulation of Securities, 32 Bus. Law. 1925, 1930 (1977). Pension plans which are not defined benefit plans are defined contribution plans. Under a defined contribution plan each participant in the plan has an individual account. Pension benefits are based solely on the contributions made to the participant's account plus all income, expenses, gains, and losses attributable to the account plus any forfeitures of accounts of other participants that are allocated to the participant's account. See Employee Retirement Income Security Act of 1974 [hereinafter cited as ERISA] § 3(34), 29 U.S.C. ₹ 1002(34) (Supp. V 1975). 
pension plans ${ }^{5}$ has led quite naturally to an increase in the number of abuses and disputes surrounding them ${ }^{6}$ Congress attempted to deal with many of these abuses by enacting the Employee Retirement Income Security Act of 1974 (ERISA) ${ }^{7}$ Recently, the Seventh Circuit, in Daniel $v$. International Brotherhood of Teamsters, ${ }^{8}$ accepted the argument that the federal securities laws provide additional remedies, and held that noncontributory pension plans are subject to the antifraud provisions of the securities laws.

This comment examines legislative history and Supreme Court "investment contract" precedent in order to determine whether the federal securities laws are applicable to noncontributory, defined benefit pension plans. ${ }^{9}$

\section{The Statutes and Congressional INTent}

\section{A transaction does not fall within the scope of either the Securi-}

S In 1940, assets of private pension plans were estimated to be $\$ 2.4$ billion. By 1973 these assets had grown to $\$ 150$ billion; estimates for 1980 indicate that assets will probably exceed $\$ 250$ billion. S. REP. No. 127, 93d Cong., 2d Sess. 2-3 (1973). Moreover, these figures understate the magnitude of private pension plan liabilities. Assets of private pension plans represent only the funded portion of private pension plan liabilities. Reported unfunded liabilities are currently in excess of $\$ 50$ billion. Indeed, as noted by one commentator: "There is reason to believe . . . that the reported figures are ridiculously understated. Unfunded liabilities might actually come to several hundred billion dollars." Ehrbar, Those Pension Plans Are Even Weaker Than You Think, ForTUNE, November, 1977, at 104.

- See S. REp. No. 127, 93d Cong., 2d Sess. 2-3 (1973). One commentator, for example, stated that:

Prior to the ?ension Reform Act [ERISA], Congressional debates, television programs, the news media, and many articles and books spotlighted certain defects of private pension plans, emphasizing in particular the plight of individuals without pension benefits after years of plan membership. Some of the horrible examples included workers who just missed their pension by not having enough service with their employer, some who worked for an employer whose business failed or was taken over by another concern, some who lost their job before benefits vested. But the message was the same-insecurity for the individual in old age.

W. GreENOUGH \& F. King, supra note 1 , at 154 .

${ }^{7}$ Pub. L. No. 93-406, 88 Stat. 829 (codified at 29 U.S.C. $\$ \S 1001-1381$ (Supp. V 1975)).

× 561 F.2d 1223 (7th Cir. 1977), petition for cert. filed, 46 U.S.L.W. 3374 (U.S. Dec. 6, 1977) (Nos. 77-753 \& 77-754). Other recent decisions have reached a contrary result. Wiens v. International Bhd. of Teamsters, [1977] Fed. SEc. L. REP. (CCH) I 96,005 (C.D. Cal. March 28, 1977); Hurn v. Retirement Fund Trust of Plumbing, Heating \& Piping Indus., 424 F. Supp. 80 (C.D. Cal. 1976). Cf. Robinson v. UMW Health and Retirement Funds, 435 F. Supp. 245 (D.D.C. 1977) (dismissing federal securities law claim in context of employee welfare benefit plan litigation).

- It is well established that employee interests in contributory private pension plans, at least in some circumstances, are subject to the federal securities laws. See generally Mundheim \& Henderson, The Applicability of the Federal Securities Laws to Pension and Profit-Sharing Plans, 29 LAw \& ConTemp. Prob. 795 (1964). For this reason, this comment will deal only tangentially with contributory plans. 
ties Act of $1933^{10}$ or the Securities Exchange Act of 1934," unless it involves a "sale" or "offer for sale" of a "security." The term "security" is defined in section 2(1) of the Securities Act of 1933:

[T] he term "security" means any note, stock, treasury stock, bond, debenture, evidence of indebtedness, certificate of interest or participation in any profit-sharing agreement, collateral-trust certificate, preorganization certificate or subscription, transferable share, investment contract, voting-trust certificate, certificate of deposit for a security, fractional undivided interest in oil, gas, or other mineral rights, or, in general, any interest or instrument commonly known as a "security," or any certificate of interest or participation in, temporary or interim certificate for, receipt for, guarantee of, or warrant or right to subscribe to or purchase, any of the foregoing. ${ }^{12}$

A similar definition of "security" appears in section 3(a)(10) of the 1934 Securities Exchange Act, ${ }^{13}$ and the courts have held that the two definitions are substantially equivalent. ${ }^{14}$

This definition of "security" does not, at first glance, seem to include employees' interests in noncontributory private pension plans. Section 2(1) does not mention the terms "employee interest," "noncontributory private pension plan," or even "pension" or "retirement benefits." However, this does not foreclose the possibility that pension plans are encompassed within the statutory definition.

The legislative histories of the 1933 Securities Act and the 1934

\author{
${ }^{10} 15$ U.S.C. $\S \S 77 a-77 a a$ (1970). \\ I1 15 U.S.C. $\S \S 78 \mathrm{a}-78 \mathrm{hh}(1970)$. \\ 1215 U.S.C. $\& 77 \mathrm{~b}(1)(1970)$. \\ 13 This section states: \\ When used in this title unless the context otherwise requires-
}

(10) The term "security" means any note, stock, treasury stock, bond, debenture, certificate of interest or participation in any profit-sharing agreement or in any oil, gas, or other mineral royalty or lease, any collateral-trust certificate, preorganization certificate or subscription, transferable share, investment contract, voting-trust certificate, certificate of deposit, for a security, or in general, any instrument commonly known as a "security" or any certificate of interest or participation in, temporary or interim certificate for, receipt for, or warrant or right to subscribe to or purchase, any of the foregoing; but shall not include currency or any note, draft, bill of exchange, or banker's acceptance which has a maturity at the time of issuance of not exceeding nine months, exclusive of days of grace, or any renewal thereof the maturity of which is likewise limited.

15 U.S.C. $\S 78 \mathrm{c}(a)(10)(1970)$.

"See, e.g., United Housing Foundation, Inc. v. Forman, 421 U.S. 837, 847 n.12 (1975);

Tcherepnin v. Knight, 389 U.S. 332, 336, 342 (1967). 
Securities Exchange Act provide little guidance in resolving the issue; there is no mention of pension plans in any of the congressional discussions prior to the passage of the Acts. ${ }^{15}$ While this may reflect the fact that "pension plans were still a rarity" in the 1930 's, ${ }^{16}$ it does not necessarily follow that Congress specifically intended to exclude such plans from the definition of "security." Congress was primarily concerned with enacting legislation to curb "serious abuses" in the capital markets" ring in connection with "the sale of securities to raise capital for profit-making purposes." 18 Because of the relative insignificance of pension plan abuses at that time, it is probable that Congress gave little, if any, thought to the question whether interests in pension plans are securities under section 2(1).

In 1934, several amendments to the 1933 Act were proposed, ${ }^{19}$ including a provision specifically exempting from registration "an offering made solely to employees of an issuer or its affiliates in connection with a bona fide plan for the payment of extra compensation or stock-investment plan for the exclusive benefit of such employees."20 This provision, however, was eventually rejected by the House-Senate Conference Committee because the Committee believed that "the participants in employees' stock-investment plans may be in as great need of protection afforded by availability of information concerning the issuer for which they work as are most other members of the public."21

This statement indicates that the Conference Committee viewed interests in employee stock-investment plans as "securities" within the meaning of section $2(1)$. Since the committee's only explicit reference was to "stock-investment plans,"22 it cannot be assumed that the committee would have necessarily concluded that noncontributory, defined benefit pension plans were also subject to the Act. Stock-investment plans, by their very nature, are closely related to the types of securities explicitly covered by section 2(1) because stock-investment plans generally involve a direct investment by the employee in the stock of his employer's company. ${ }^{23}$

is See, e.g., Daniel v. International Bhd. of Teamsters, 561 F.2d 1223, 1237 (7th Cir. 1977), petition for cert. filed, 46 U.S.L.W. 3374 (U.S. Dec. 6, 1977) (Nos. 77-753 \& 77-754).

16 Id. at 1241 .

17 United Housing Foundation, Inc. v. Forman, 421 U.S. 837, 849 (1975).

is Id.

1" Securities Exchange Act of 1934, ch. 404, 48 Stat. 881 (1934).

2078 CoNG. Rec. 8708 (1934).

${ }^{21}$ H.R. REP. No. 1838, 73d Cong., 2d Sess. 41 (1934).

nId.

2see, e.g., SEC v. Ralston Purina Co., 346 U.S. 119 (1953). 
Employees who participate in such plans are as much in need of full disclosure as any other investor. ${ }^{24}$ Pension plans, by contrast, do not involve a direct employee investment in a security. Although the pension funds may be invested in securities, the employees covered under a noncontributory, defined benefit pension plan have only a claim to pension benefits. Thus, the need for disclosure may be substantially less. ${ }^{25}$

In 1941, the Securities and Exchange Commission proposed amendments exempting specific types of pension plans from the registration requirements of the 1933 Act. ${ }^{26}$ Although none of these amendments were enacted, industry reaction to the proposals indicates that these plans were not generally thought to be securities within the meaning of section $2(1)$. No industry witness testified on behalf of the amendments. ${ }^{27}$ Indeed, several industry witnesses testified against them and "argued that Congress should not adopt the amendments because adoption would have the effect of sanctioning the Commission's construction of the act and would thus cause the act to become applicable to any employee plan which did not meet the terms of any exemption granted pursuant to the amendments." 28 The failure of Congress to enact the amendments, however, indicates little about its view of the pension plan question because American involvement in World War II foreclosed serious consideration of the matter. ${ }^{29}$

More recent legislative action might be taken to suggest that Congress views all pension interests as securities. Section $27(\mathrm{~b})$ of the Investment Company Amendments Act of $1970^{30}$ amended the 1933 Securities Act by exempting certain classes of "securities" from the registration requirements of section $5,{ }^{31}$ including

21 Id.

${ }^{25}$ For example, the early SEC position was that there was no sale of a noncontributory pension interest because there was "no element of volition on the part of the employees whether or not to participate . . . Op. SEC Ass't Gen. Counsel (1941), 1 Pens. Plan Guide (CCH) I 1104.101. According to one commentator, the SEC's position was "that if the employee has no real choice with respect to the medium in which his funds are invested there would be only a limited usefulness in requiring disclosure." Mundheim \& Henderson, supra note 9 , at $807-08$.

${ }^{26}$ See Proposed Amendments to the Securities Act of 1933 and to the Securities Exchange Act of 1934: Hearings before the House Comm. on Interstate and Foreign Commerce, 77th Cong., 1st Sess. 907-08, 950 (1941) [hereinafter cited as 1941 Hearings].

27 Mundheim \& Henderson, supra note 9, at 811-12.

${ }^{28} I d$.

29 Id. at 811.

so Pub. L. No. 91-547, 84 Stat. 1434 (codified at 15 U.S.C. $\$ 77 c(a)(2)(1970)$ ).

» 15 U.S.C. $\$ 77 \mathrm{e}(1970)$. 
any interest or participation in a single or collective trust fund maintained by a bank or in a separate account maintained by an insurance company which interest or participation is issued in connection with ... a stock bonus, pension, or profitsharing plan which meets the requirements for qualification under 401 of the Internal Revenue Code of $1954 \ldots . .32$

It could be argued that Congress's labeling of pension plan interests as "securities" for the purposes of the section 3(a) exemption-after its rejection of similar amendments-evidences its belief that all such interests fall within the section 2(1) definition of a security. ${ }^{33}$ Other considerations suggest that this was not the case. First, the main purpose of the amendment was to codify previous Commission practices in exempting certain pension interests from the filing and registration requirements of the 1933 Act..$^{34}$ Although section 3(a) refers to pension interests as securities, the amendment was intended to assure concerned parties that registration would not be required; it was not intended to aid in defining the term "security." Pension interests may have been included within the general exemption clause merely as a matter of convenience. Secondly, the draftsmanship of the 1970 amendments strongly counsels against searching its terms for evidence of considered legislative judgment on matters collateral to the purposes of the legislation. It is widely acknowledged that the 1970 Act is not a model of clarity; ${ }^{35}$ indeed, it was amended within a week of its enactment in order to forestall possible misinterpretations. ${ }^{36}$ In view of the Act's general imprecision, it is doubtful whether Congress carefully considered the various types of pension interests and concluded that each is a security under section $2(1)$.

Aside from the 1970 legislation, there is nothing to suggest that Congress views pension plan interests in general as subject to the securities acts. Indeed, the conclusion to be drawn from the legislative history of those acts that specifically focus on employee benefit interests is that Congress believed there was "no Federal Statute, regulation or authority" that provided protection for pension plan

32 Pub. L. No. 91-547, 84 Stat. 1413, 1434. The Act specifically refers to these interests as "securities."

7 Daniel v. International Bhd. of Teamsters, 561 F.2d 1223 (7th Cir. 1977), petition for cert. filed, 46 U.S.L.W. 3374 (U.S. Dec. 6, 1977) (Nos. 77-753 \& 77-754).

31 Op. SEC Ass't Gen. Counsel, supra note 25, at ๆ 1104.101.

as See, e.g., Friedman, The Securities Act of 1933 and Employee Compensation Plans, in Fourth Annual Institute On Securities Regulation 353, 368 (1973).

36 Act of Dec. 22, 1970, Pub. L. No. 91-567, 84 Stat. 1497 (1970). 
beneficiaries. ${ }^{37}$ For example, during hearings on the Welfare Pension Plan Disclosure Act of $1959,{ }^{38}$ Senator John Kennedy dramatized the problem by contrasting the general "inadequacies of safeguards"39 designed to protect employee benefit plans with "the protection furnished comparable large-scale public savings and investments by the Federal Deposit Insurance Act, the Securities and Exchange Act of 1933 [sic], the Investment Company Act of 1940, and so forth." 40 The absence of comprehensive protection provided the impetus for the federal legislative efforts resulting in ERISA." The Senate Report on that legislation stated that "[p]ension . . . plans are exempt from coverage under the Securities Act of 1933 ... unless the plan is a voluntary contributory pension plan and invests in the securities of the employer company an amount greater than that paid into the plan by the employer." 42

In sum, the relevant legislative history of the securities acts and employee benefits legislation suggests that Congress never definitively indicated whether noncontributory pension plan interests are securities. Furthermore, as the Supreme Court has stated, "Congress did not attempt to articulate the relevant economic criteria" 43 for determining if a particular interest is or is not a security. Thus, "the task has fallen to the Securities and Exchange Commission and . . . ultimately to the federal courts to decide which of the myriad financial transactions in our society come within the coverage of these statutes." 44

\section{The SEC AND the Courts}

\section{A. The Position of the SEC}

The SEC has consistently taken the position that interests in employee benefit plans are securities. ${ }^{45}$ In 1941 , the Commission

${ }^{37}$ S. REP. No. 1734, 84th Cong., 2d Sess. 60 (1956).

3829 U.S.C. $\$ \S 301-309$ (1970) (repealed by Employee Retirement Income Security Act of 1974, Pub. L. No. 93-406, 88 Stat. $829 \S 111$ (a)(1) (codified at 29 U.S.C. $\$ 1031$ (a)(1) (Supp. V 1975))).

30 S. REp. No. 1440, 85th Cong., 2d Sess. 9 (1958).

"id.

" 29 U.S.C. $\$ \S 1001-1381$ (Supp. V 1975).

${ }^{42}$ Interim Report of the Private Welfare and Pension Plan Study, S. Rep. No. 634, 92d Cong., $2 d$ Sess. 96 (1971). The final report adopted the INTERIM Report as a "complete description of the federal regulation affecting the administration of private [pension] plans ...."S. Rep. No. 127, 93d Cong., 1st Sess. 4 (1973).

${ }^{43}$ United Housing Foundation, Inc. v. Forman, 421 U.S. 837, 847 (1975).

"Id. at 848 .

${ }^{15}$ The SEC first adopted this position in 1934, in response to the congressional rejection of an amendment that would have exempted stock investment plans from the registration provisions of the 1933 Act. See text and notes at notes 19-21 supra. 
advocated congressional adoption of an amendment to the 1933 Securities Act that would have explicitly exempted certain pension plans from the registration requirements of section $5 .{ }^{46}$ The Commission also supported an amendment delegating to it the power to exempt benefit plans, including pension plans, pursuant to its rulemaking authority. ${ }^{47}$ At the same time, however, the SEC opposed another proposal to remove all pension plans qualifying under what is now section 401 of the Internal Revenue Code from the definition of "security." 48 The Commission's opposition to this sweeping exemption is consistent with its support for limited exemptions from registration and clearly indicates its belief that interests in certain kinds of benefit plans should be afforded protection under the securities acts. Although these amendments were never enacted, ${ }^{49}$ an opinion of counsel issued in 1941 formally expressed the Commission's view that certain interests in benefit plans were "securities." The opinion stated that "the security which is involved within the meaning of section 2(1) of [the 1933 Act] in connection with the offer or sale of interests on certain types of plans is normally an 'investment contract."' 51

In testimony at a Senate subcommittee hearing on ERISA, former SEC Chairman Manuel F. Cohen explained the Commission's view:

In many respects, pension plans and mutual funds have features in common . . . . First, both investor and employee are investing money which they have earned. There is no gratuity involved. Realistically, the employee is simply putting into a fund for his future use that which he would otherwise get in his paycheck. And the employer finds it to be in his interest to contribute to that fund and to do so under circumstances which will stimulate contributions by his employees. Both the investor and the employee-and the employer-place their confidence and trust in an administrator who is in a position to exercise expert judgment concerning the management of their funds..$^{2}$

*1 1941 Hearings, supra note 26, at 907-08, 950.

17 Id.

13 Id. at 919-20.

"See text and note at note 29 supra.

so Op. SEC Ass't Gen. Counsel, supra note 25, at \ 1104.101.

st Id.

${ }^{52}$ Hearings on S. 3598 Before the Subcomm. on Labor of the Senate Comm. on Labor \& Public Welfare, 92d Cong., 2d Sess. 231 (1972). 


\section{B. The Courts}

The SEC's determination that interests in private pension plans are normally "securities" was based on the view that such interests are a species of "investment contract" as that term is used in section 2(1) of the 1933 Act. ${ }^{53}$ In the recent case of Daniel $v$. International Brotherhood of Teamsters ${ }^{54}$ the Seventh Circuit held that interests in noncontributory pension plans are "investment contracts" for the purposes of the antifraud provisions of the securities laws. ${ }^{55}$

1. The Investment Contract Concept. Although the term "investment contract" appears in the definition of "security" in both the 1933 and 1934 securities acts, neither act defines the term. ${ }^{56}$ As originally employed in state securities legislation, the term applied only to certain out-of-state land sales.$^{57}$ However, the scope of the concept expanded when state courts began to recognize that "investment contract" could be transposed into "contract which is an investment. ${ }^{158}$ Current interpretations of the term in the context of the federal securities laws have retained this broader scope so that, as one commentator has noted, "investment contract" is the " 'catchall that isn't otherwise caught' provision" 59 of the securities acts.

The leading case defining "investment contract" for purposes of the federal securities laws is $S E C v$. W.J. Howey $\mathrm{Co}^{60} \mathrm{In}$ Howey, a land sales corporation sold small tracts of citrus grove land to plaintiffs. The plaintiffs were simultaneously offered cultivation and marketing services to be provided by a corporation controlled by the sales corporation, and the two contracts were found to constitute a single investment in the agricultural venture.$^{61}$ Noting that "investment contract" had generally been defined under state law as "the placing of capital or laying out of money in a way intended

53 See text and notes at notes 12-14 supra.

st 561 F.2d 1223 (7th Cir. 1977), petition for cert. filed, 46 U.S.L.W. 3374 (U.S. Dec. 6, 1977) (Nos. 77-753 \& 77-754).

5s Id, at 1231 .

s6 15 U.S.C. $\$ 77 \mathrm{~b}(1)(1970) ; 15$ U.S.C. $\$ 78 \mathrm{c}(\mathrm{a})(10)(1970)$. The term "investment contract," as well as the entire definition of "security" found in the 1933 Act, were taken virtually verbatim from the third tentative draft of the Uniform Sale of Securities Act, which appeared in 1927. See Note, Pension Plans as Securities, 96 U. PA. L. Rev. 549, 553 (1948).

${ }^{77}$ See Note, Pension Plans as Securities, 96 U. PA. L. Rev. 549, 553 (1948).

s8 See, e.g., State v. Evans, 154 Minn. 95, 191 N.W. 425 (1922); State v. Gopher Tire \& Rubber Co., 146 Minn. 52, 177 N.W. 937 (1920).

39 Bloomenthal, The Many Faces of a Security, 22 Prac. Law. 45 (1976).

so 328 U.S. 293 (1946).

sI Id. at 299-300. 
to secure income or profit from its employment," that "an investment contract for purposes of the Securities Act means a contract, transaction or scheme whereby a person invests his money in a common enterprise and is led to expect profits solely from the efforts of the promoter or a third party."

The investment contract test formulated in Howey has changed slightly in recent years. Several decisions have somewhat relaxed the requirement that profits be produced "solely" by the efforts of others. ${ }^{64}$ The Ninth Circuit, in SEC $v$. Glenn Turner Enterprises, Inc. ${ }^{65}$ held that an investment contract exists if profits are expected to derive from the "essential managerial efforts of third parties." Although the Supreme Court has not squarely approved this standard, it has recently stated that "[t]he touchstone [of an investment contract] is the presence of an investment in a common venture premised on a reasonable expectation of profits to be derived from the entrepreneurial or managerial efforts of others." ${ }_{67}$ Thus, in order to satisfy the Howey "investment contract" test, as revised, there must be a finding of (1) an investment (2) in a common enterprise (3) with the expectation of profits (4) derived from the managerial efforts of third parties.

Some courts and commentators have suggested that the Supreme Court's recent decision in United Housing Foundation, Inc. v. Forman ${ }^{68}$ represents a shift in emphasis by the Court. ${ }^{69}$ Forman, in part, presented the question whether stock in a cooperative housing project was a security within the "investment contract" definition. The Court rejected the argument that these were "investment contracts," on the ground that "neither of the kinds of profits traditionally associated with securities was offered to [plaintiffs]."70 Moreover, the Court stated that Congress intended application of the securities laws "to turn on the economic realities underlying a

'I Id. at 298.

w Id. at 298-99.

4 See, e.g., SEC v. Koscot Interplanetary, Inc., 497 F.2d 473 (5th Cir. 1974); SEC v. Glenn W. Turner Enterprises, Inc., 474 F.2d 476 (9th Cir. 1973).

is 474 F.2d 476 (9th Cir. 1973).

" Id. at 483.

in United Housing Foundation, Inc. v. Forman, 421 U.S. 837, 852 (1975).

a* 421 U.S. 837 (1975).

- E.g., Lowenfels, Recent Supreme Court Decisions under the Federal Securities Laws: The Pendulum Swings, 65 GEO. L.J. 891, 906-11 (1977); cf. Brief of the Securities and Exchange Commission, Amicus Curiae at 21, Daniel v. International Bhd. of Teamsters, 561 F.2d 1223 (7th Cir. 1977) ("The Forman decision is in no way inconsistent with the principles enunciated in the previous decisions.").

${ }^{70} 421$ U.S. at 854 . 
transaction, and not on the name appended thereto."'71 In stressing the need to consider "economic realities," however, the Court operated within the framework of the Howey test; indeed, it stated that the Howey test was the "basic test for distinguishing the transaction from other commercial dealings." 72 Furthermore, the Court's emphasis on "economic realities" represents a consistent trend throughout its opinions on investment contracts. In Howey the Court remarked that form should be "disregarded for substance and emphasis . . . placed upon economic reality." "73 Thus, although Forman was the first case in which the Supreme Court reversed a lower court holding that a particular transaction involved an "investment contract," 74 the Court did not depart from the Howey test.

2. Noncontributory Pension Plans in the Lower Courts. The only case holding that an interest in a noncontributory private pension plan is an "investment contract" is Daniel $v$. International Brotherhood of Teamsters. ${ }^{75}$ The plaintiff in Daniel was denied pension benefits because he had failed to satisfy his union's pension plan requirement of twenty years of continuous service. Although he had been a teamster for over twenty-two years, he had been laidoff for four months in 1960-61 because of adverse economic conditions. ${ }^{76}$ The district court held that pension plan interests were "securities" and that the plaintiff had stated a cause of action under section 17(a) of the 1933 Act and section 10(b) and rule 10b-5 of the 1934 Act. $^{77}$

7I. Id. at 849 .

72 Id. at 852 .

7328 U.S. at 298. The Court used almost identical language in Tcherepnin v. Knight, 389 U.S. 332, 336 (1967) ("form should be disregarded for substance and the emphasis should be on economic reality").

${ }^{74}$ In all of the previous cases, the Supreme Court found that the transaction at issue involved a security. See Tcherepnin v. Knight, 389 U.S. 332 (1967) (holding a withdrawable capital share in a savings and loan to be a security); SEC v. United Benefit Life Ins. Co., 387 U.S. 202 (1967) (holding a variable annuity contract with a guaranteed minimum to be a security); SEC v. Variable Annuity Life Ins. Co., 359 U.S. 65 (1965) (holding a variable annuity contract to be a security); SEC v. W.J. Howey Co., 328 U.S. 293 (1946) (holding a land sales contract in conjunction with a service contract to be a security); SEC v. C.M. Joiner Leasing Corp., 320 U.S. 344 (1943) (holding an oil exploration program in conjunction with a land lease to be a security).

${ }^{75} 410$ F. Supp. 541 (N.D. Ill. 1976), aff'd, 561 F.2d 1223 (7th Cir. 1977), petition for cert. filed, 46 U.S.L.W. 3374 (U.S. Dec. 6, 1977) (Nos. 77-753 \& 77-754)،

7 561 F.2d at 1226. The union's plan provided that an employee who had been laid off could contribute to the pension fund. Thus, in a sense, the pension plan was neither compulsory nor noncontributory. Brief of the Securities and Exchange Commission, Amicus Curiae at 12, Daniel v. International Bhd. of Teamsters, 561 F.2d 1223 (7th Cir. 1977).

$n 410 \mathrm{~F}$. Supp at 553. 
In affirming the district court's decision, the Seventh Circuit analyzed the Daniel plan in terms of the four elements of the Howey test. ${ }^{88}$ The court found that an "investment" had been made when the "employers . . . [put] money into a fund for an employee's future use which he would otherwise be getting in his paycheck."79 A "common enterprise" was clearly involved in the plan since the employer's contributions constituted a trust fund in which the beneficiaries had an undivided interest..$^{80}$ Isolating the "profit" element in the plan presented some difficulty. The court concluded that since "the expected payout to a beneficiary will exceed the contributions made by the employer on the employee's behalf . . . [ $t$ ]he resulting gain would commonly be termed a profit."81 Finally, the court identified the fourth element-the "managerial efforts of third parties"-in the trustee's exercise of exclusive control over the pension fund. ${ }^{82}$

Although the Seventh Circuit seems to have had little difficulty in concluding that pension plans are a form of investment contract, other courts have disagreed..$^{83}$ Unfortunately, the reasoning of these decisions has not been particularly helpful. In Hurn $v$. Retirement Fund Trust of Plumbing, Heating and Piping Industry, ${ }^{84}$ for example, the district court apparently thought that the issue was so clear that no analysis was required. In dismissing the cause of action, the court merely cited Forman and stated that the "Plaintiff's interest in the . . . [pension trust fund] is not a 'security' within the meaning of the Securities Law." 85 The court in Wiens $v$. International Brotherhood of Teamsters ${ }^{88}$ was even less sympathetic to the plaintiff's claim that his pension interest was a security. After asserting that "for forty years the SEC has said that these pension plan interests were not securities,"

${ }^{73}$ See text and notes at notes 63-67 supra.

7 $561 \mathrm{~F} .2 \mathrm{~d}$ at 1232.

so The court stated that "the common enterprise can properly take the form of a trust fund investing in the capital markets where the beneficiaries' common relationship with the enterprise is an undivided interest in such a trust." Id. at 1233.

si Id. at 1234.

"22 The court stated that "[t]he pension fund trustees self-admittedly exercise exclusive control over the common enterprise and investment of its assets." Id. at 1233.

s See, e.g., Wiens v. International Bhd. of Teamsters, [1977] FED. SEc. L. REP. (CCH) If 96,005 (C.D. Cal. March 28, 1977); Hurn v. Retirement Fund Trust of Plumbing, Heating \& Piping Indus., 424 F. Supp. 80 (C.D. Cal. 1976).

s 424 F. Supp. 80 (C.D. Cal. 1976).

is Id. at 81 .

a [1977] FEd. SEC. L. REP. (CCH) ๆ 96,005 (C.D. Cal. March 28, 1977).

${ }^{87}$ Id. at 91,519 . 
the temerity to argue that this [pension interest] was a security." 88 The court's assertion is, of course, simply incorrect; the SEC has consistently maintained that pension interests are "securities" within the definition of the 1933 Act. ${ }^{89}$

The Hurn and Wiens decisions can perhaps be supported by the analysis adopted in Robinson v. UMW Health \& Retirement Funds, ${ }^{90}$ even though that case did not present the issue of interests in a noncontributory pension fund. Plaintiffs in Robinson instituted a class action on behalf of the surviving spouses and dependents of deceased coal miners seeking a declaration of their rights to permanent health care coverage under the union's health and retirement plan. The district court dismissed the securities law claim, rejecting the reasoning of the district court in Daniel on the ground that Daniel had stretched the definition of a security to a degree "unwarranted by the realities of the transactions and the function and purpose of the securities laws." 91 The court applied the Howey test and found certain elements lacking:

[T]rust participation involves no "expectation of profit" in the sense found necessary in Howey and Forman . . . . The miners, in bargaining for establishment of the Trust [in this case], were obviously interested in creating a sound, comprehensive health plan, "rather than making an investment for profit." The Trust simply cannot be characterized as one of the "countless and variable schemes devised by those who seek the use of money of others on the promise of profits."

The Daniel and Robinson decisions perhaps could be reconciled on the basis of the differences between noncontributory pension plans on the one hand and the health and retirement plan in the Robinson case on the other. ${ }^{83}$ But the Robinson court's express rejec-

s. Id. at 91,521 .

se See text and notes at notes $45-52$ supra.

9045 F. Supp. 245 (D.D.C. 1977).

"Id. at 246 .

92 Id, at 246.47 .

${ }^{93}$ Indeed, the Robinson court admitted, without further elaboration, that "Daniel is distinguishable from the instant case." 435 F. Supp. at 246 n.1. The Seventh Circuit in Daniel distinguished Robinson partly on the ground that the plaintiffs in Robinson had not themselves contributed anything to the employers in exchange for the employers' payments into the fund, and that there had therefore been no "sale." 561 F.2d at 1235 . The court also emphasized that there "was no expectation of profit in Robinson because benefits were to be paid out of the employers' current contributions to the trust rather than from the fund's capital." Id. 
tion of the district court's analysis in Daniel suggests a sharp disagreement over the proper interpretation of Howey and Forman. ${ }^{94}$

\section{Application of the Investment Contract Test}

In Howey, the Supreme Court defined "investment contract" as a contract "whereby a person invests his money" in a common enterprise managed by third parties with a reasonable expectation of receiving a share in the profits of the enterprise..$^{95}$ In the pension plan context, the difficult issue is whether the employee-participant makes an investment for profit.

\section{A. The Investment}

1. Daniel. A person "invests" in an enterprise when he relinquishes resources to the enterprise in exchange for a right to share in the income that the enterprise will generate. In the usual case the investment takes the form of a cash contribution to the enterprise, but it may take other forms, including the rendering of services.

In the case of noncontributory pensions the employee, by definition, makes no cash contribution. In Daniel the court found that an investment had been made by the employee through the employer's contribution to the fund because the money contributed would have gone to the employee as wages in the absence of the pension plan ${ }^{98}$ The court rejected the view "that there is a controlling conceptual distinction between 'non-contributory' plans and plans where the employee first receives cash and then pays over such cash into the pension fund" as a subscription to "undue literalism. "97 If the employer's contributions to the fund are thus linked to the employee, the noncontributory pension plan can be easily analogized to a mutual fund..$^{98}$

" The court of appeals' opinion in Daniel did not respond to the Robinson court's statement that the application of the securities laws to the fact situation in Daniel was "unwarranted by the realities of the transactions."

is 328 U.S. 293, 298-99 (1946). See text and notes at notes 60-74 supra.

" 561 F.2d at 1232.

" 561 F.2d at 1243. A similar theory is set forth in de Roode, Pensions as Wages, 3 AM. EcoN. REv. 287 (1913). The Daniel court relied on a discussion in Mundheim \& Henderson, supra note 9, at 803-04. However, their discussion concerns the characterization of the pension trust. Mundheim and Henderson use the characterization of the Senate Labor Committee that "[r]egardless of the form they take, the employers' share of the cost of these plans or the benefits the employers provide are a form of compensation," S. REP. No. 1440, 85th Cong., $2 \mathrm{~d}$ Sess. 4 (1958), to reach the conclusion that the pension trust is "created for business purposes and is not non-commercial." Mundheim \& Henderson, supra note 9, at 804. This is contrasted with the view that "the creation of a pension plan by an employer . . . [is] a gift ...." Id. at 803 .

" Former SEC Chairman Cohen explained to the Senate Subcommittee on Labor of the 
To support its view that the employer's contributions represent the employee's investment the court turned to its decision in Inland Steel Co. v. NLRB. ${ }^{99}$ In Inland Steel, the Seventh Circuit concluded that pension and retirement benefits are mandatory subjects of collective bargaining under the National Labor Relations Act. ${ }^{100}$ The court there stated that "realistically viewed, this type of wage enhancement or increase . . . becomes an integral part of the entire wage structure."101 The Daniel court apparently reasoned that retirement benefits are the functional equivalent of wages paid for services rendered because employees, through their collective bargaining agent, can trade off retirement benefits against present wages. The "realism" of the Inland Steel case is hardly compelling support for this view. Although a pension plan may be a collectively bargained-for "condition of employment," it does not follow that individual pension interests are purchased by foregone wages.

2. Judicial Treatment of Pension Interests in Other Contexts. It will be helpful, taking a cue from Daniel, to examine how courts have viewed interests in noncontributory pension plans for other legal purposes.

Pension plans were originally viewed as gratuitous in nature. ${ }^{102}$ But the view that the employer receives no benefit in exchange for the pension interest did not seem to accord with reality, and the legal consequences of the theory were harsh. In response most jurisdictions repudiated the gratuity theory and now view noncontributory pension plans as contracts. ${ }^{103}$ The contract, however, does not arise until the employee satisfies the plan's vesting requirements. ${ }^{104}$

Senate Committee on Labor \& Public Welfare: "In many respects, pension plans and mutua funds have features in common . . . . First, both investor and employee are investing money which they have earned. . . . Both the investor and the employee . . . place their confidence and trust in an administrator who is in a position to exercise expert judgment concerning the management of their funds . . . " Hearings on S. 3598 before the Subcomm. on Labor of the Senate Comm. on Labor \& Public Welfare, 92d Cong., 2d Sess. 231 (1972).

93 170 F.2d 247 (7th Cir. 1948), cert. denied in part, 336 U.S. 960 (1949), aff'd on other grounds, 339 U.S. $382(1950)$.

100 Id. at 249.

101 Id.

102 See, e.g., McNeven v. Solvay Process Co., 32 App. Div. 610, 53 N.Y.S. 98 (1898), aff'd without opinion, 167 N.Y. 530, 60 N.E. 115 (1901) (the first case explicitly dealing with this issue and holding that a pension was an "inchoate gift"); Friedman v. Romaine, 77 Misc. $2 \mathrm{~d}$ 134, 140, 352 N.Y.S.2d 351, 357 (Sup. Ct. 1974) ("It has long been the law with respect to pension plans . . . which are not the outgrowth of collective bargaining agreement that . . . the benefits conferred thereby are gratuities."). See generally B. AARON, LEGAL STATUS or Employee Benefit Rights under Private Pension Plans 5-9 (1961).

${ }^{103}$ See, e.g., Craig v. Bemis Co., 517 F.2d 677, 680 (5th Cir. 1975); Morse v. J. Ray McDermott \& Co., 344 So. 2d 1353, 1357 (La. 1977). See also Annot., 42 A.L.R.2d 461 (1955).

ios See B. Aaron, supra note 102, at 9-10; A. Corbin, Contracts $\S 153$ (1952); Annot., 42 A.L.R.2d 461, 468.69 (1955). 
The pension plan is conceptualized as an offer by the employer that the employee can accept only by fulfilling all the vesting requirements, typically including the requirement that the employee remain in the employer's service for a stated period of time. ${ }^{105}$ If the employee fails to satisfy the vesting requirements, there is no acceptance, and hence no contract. ${ }^{106}$ According to Corbin, "part performance of the bargained for consideration, forming a part of the expected process of acceptance, is now held to make the offer irrevocable although the duty of the offeror is conditional upon completion by the offeree." 107

Despite the consensus that an employer receives value in exchange for the benefits paid out under a noncontributory plan, ${ }^{108}$ the courts enforce the pension contract in strict accordance with its terms. ${ }^{109}$ They "have been uniformly reluctant to grant terminated

10s See, e.g., Taylor v. Multnomah County Deputy Sheriff's Retirement Bd., 265 Or. 445, 510 P.2d 339 (1973).

${ }_{106}$ See, e.g., Taylor v. General Tel. Co., 20 Cal. App. 3d 70, 97 Cal. Rptr. 349 (1971).

${ }^{107}$ A. CorBin, supra note $104, \S 153$ at 224.

tox Because the employer receives value it should be clear that noncontributory pension plans involve a sale or offer to sell a pension interest.

The SEC once took the position that such plans were not subject to the securities laws because "no 'offer' or 'sale' is involved in the case of a non-contributory plan." Op. SEC Ass't Gen. Counsel, supra note 25, at I 1104.101. As explained by SEC Commissioner Purcell, the SEC viewed pension interests as bonuses or gifts. 1941 Hearings, supra note 26, at 896. The SEC's position accorded with the view of many courts at that time that pension interests were gifts. That view appears indefensible now that most courts view pensions as contracts. See text and notes at notes 102-107 supra. Section 2(3) of the 1933 Act, 15 U.S.C. \$ 77b(3) (1970), defines "sale" to include "every contract of sale or disposition of a security or interest in a security for value." The 1934 Act definition drops the "for value" requirement: "sale" includes "any contract to sell or otherwise dispose of" a security. 15 U.S.C. $\$ 78 c(a)(14)(1970)$. Under a literal reading of the 1934 Act definition there would be no difficulty finding a sale. Even under the apparently less inclusive definition found in the 1933 Act, it appears that the pension transaction is a sale or an offer to sell. The vesting provisions of the pension plan insure that the employer will receive "value" in exchange for the pension interest. Regardless of when the actual sale can be said to occur, the pension plan is easily conceptualized as an offer to transfer a pension interest "for value."

Indeed, the SEC partially abandoned its "no-sale" position in its amicus brief in Daniel, and urged upon the court the theory that noncontributory pension plans involve a sale for antifraud purposes, but not for registration purposes. Brief of the Securities and Exchange Commission, Amicus Curiae at 35-41, Daniel v. International Bhd. of Teamsters, 561 F.2d 1223 (7th Cir. 1977). The court agreed, reasoning that in view of the different purposes of the antifraud and registration provisions, "a narrow view of 'sale' would be most inappropriate as to fraudulent activity." 561 F.2d at 1244 . The SEC's dichotomous sale theory is difficult to justify because "sale" under both acts has a single definition for all purposes. It could be argued, given the absence from the 1934 Act definition of the "for value" limitation found in the 1933 Act, that it is easier to find a sale for $10 \mathrm{~b}-5$ purposes than for registration purposes, but neither the SEC nor the Daniel court relied on that variance. They drew a distinction not between the two acts but between the 1933 Act's registration provisions and the antifraud provisions of both acts.

in See, e.g., International Union, United Steel Workers v. International Sys. \& Controls 
employees vested rights in a non-contributory pension fund where the terms of the pension contract have not been literally met."110 The strict approach of the courts does not accord with the Daniel court's view that the employer's contributions to the pension fund are in reality funds the employee "would otherwise be getting in his paycheck."111 If pension contributions would otherwise be received as present wages, it might be expected that the courts would recognize a substantial performance doctrine or an unjust enrichment remedy ${ }^{112}$ in this area. That they have not suggests that the courts see the pension exchange differently from the Daniel court.

This theoretical conflict is well illustrated by the recent case of Morse v. J. Ray McDermott Co. ${ }^{13}$ In Morse, an employee who participated in a retirement plan with a fifteen-year vesting period was dismissed from his job after more than eleven years of continuous employment. On first hearing, the Louisiana Supreme Court held that when "the employee is prevented from performing his part of the bargain to complete vesting of deferred compensation benefits,"114 the non-vesting clause is "unenforceable" as contrary to the state law policy against "wage forfeitures." 115 On rehearing, the court reversed itself and ruled that employees do not acquire enforceable rights by mere service: "There is no awarding, or setting aside, in the years of employment, of any sum to the credit of the employee. There is not even a promise, or statement, that the employee has 'earned' anything in the retirement plan during his first fourteen years of company service." 116 The employer's contribution,

Corp., No. 76-1459 (10th Cir. Dec. 15, 1977); Craig v. Bemis Co., 517 F.2d 677 (5th Cir. 1975); Knoll v. Phoenix Steel Corp., 465 F.2d 1128, 1131 (3d Cir. 1972), cert. denied, 409 U.S. 1126 (1973); Schneider v. Electric Auto-Lite Co., 456 F.2d 366, 373 (6th Cir. 1972); Hudson v. John Hancock Mut. Life Ins. Co., 314 F.2d 16 (8th Cir. 1963); Schneider v. McKesson \& Robbins, Inc., 254 F.2d 827 (2d Cir. 1958); Hardy v. H.K. Porter Co., 417 F. Supp. 1175 (E.D. Pa. 1976); Avondale Mills v. Saddler, 290 So. $2 d 173$ (Ala. 1974); Jacoby v. Grays Harbor Chair \& Mfg. Co., 77 Wash. 2d 911, 920-21, 468 P.2d 666, 672 (1970); Zeimaitis v. Burlington Mills, Inc., 56 Wis.2d 449, 459, 202 N.W.2d 244, 249 (1972).

110 Lucas v. Seagrave Corp., 277 F. Supp. 338, 342 (D. Minn. 1967).

i' 561 F.2d at 1232.

112 The unjust enrichment approach has been almost unanimously rejected. See, e.g., International Union, United Steel Workers v. International Sys. \& Controls Corp., No. 761459 (10th Cir. Dec. 15, 1977); Craig v. Bemis Co., 517 F.2d 677 (5th Cir. 1975); Knoll v. Phoenix Steel Corp., 465 F.2d 1128 (3d Cir. 1972), cert. denied, 409 U.S. 1126 (1973); Hardy v. H.K. Porter Co., 417 F. Supp. 1175 (E.D. Pa. 1976); Zeimaitis v. Burlington Mills, Inc., 56 Wis.2d 449, 202 N.W.2d 244 (1972). But see Lucas v. Seagrave Corp., 277 F, Supp. 338 (D. Minn. 1967).

${ }^{113} 344$ So. 2d 1353 (La. 1977).

its Id. at 1358 .

IIs Id. at 1358-59.

118 Id. at 1369. 
according to Morse, is not linked to employee service. The court refused to look beyond the terms of the bargain in order to identify any employee equity.

The leading case that seems to adopt the Daniel "deferred wage" theory is Lucas $v$. Seagrave Corp. ${ }^{117}$ In Lucas, thirty employees who had lost their rights to pension benefits when they were dismissed by the defendant following its purchase of the employer's corporation sued for their accrued pension rights on a theory of quasi-contract. The court denied defendant's motion for summary judgment and held that the plaintiffs could recover if they showed that the defendant had terminated the relationship in a bad faith effort to "recapture" the plaintiffs' benefits. 18 The termination, the court stated, "operates only as a revocation of the employees' power of acceptance of the whole contract," and "[t]he employer must still return benefits conferred by the employee as a result of his service."119

Later decisions have explained Lucas as an attempt to find an exception for a "group termination." ${ }^{120}$ Even though the Lucas court realized that "an employer's pension plan contributions are determined by an actuarial formula which assumes that any employee whose employment is terminated forfeits his pension benefits," 121 it was nonetheless troubled by the "windfall" 122 the defendant would receive because of the group termination. The court need not have relied on the theory that pension benefits "are commonly substituted for direct cash wages," 123 nor is it clear that it did. ${ }^{124}$ Regardless of the nature and source of the benefit to the employer from having a pension plan it is clear that mass termination of jobs and hence benefit expectancies enables the employer to avoid incurring any obligations after having received substantial benefit.

3. Economic Reality. The general judicial treatment of the

17277 F. Supp. 338 (D. Minn. 1967).

I38 Id. at 346 .

11' Id. at 345 .

${ }^{120}$ See, e.g., Hardy v. H.K. Porter Co., 417 F. Supp. 1175 (E.D. Pa. 1976).

121277 F. Supp. at 345.

$122 I d$.

123 Id. at 343.

12s The Lucas court found the possibility of unjust enrichment not in the employer's retention of the employees" "deferred wages" but in the "windfall" accruing to the employer from a group termination:

[A]n employer who has discharged a relatively large number of employees receives a windfall . . . in the form of pension credit forfeitures which he can use to relieve for some time his future premium liability for the remaining employees. It seems unrealistic to say in this context ... that the employer receives nothing.

Id. at 345 . 
pension contract suggests that the courts do not see an identity between forgone wages and employer contributions. In the recent case of Alabama Power Co. v. Davis, ${ }^{125}$ the Supreme Court adopted the view, for purposes of applying section 9 of the Military Selective Services Act, ${ }^{126}$ that the "true nature" of a defined benefit pension "is a reward for length of service." 127 The Court noted that "pension payments have some resemblance to compensation for work performed," 128 but concluded that pension benefits are designed as rewards for lengthy service: "It is difficult to maintain that a pension increment is deferred compensation for a year of actual service when it is only the passage of years in the same company's employ, and not the service rendered, that entitles the employee to that increment."129

The Alabama Power opinion provides the more accurate portrayal of noncontributory pension plans. The relationship between pension benefits and forgone wages is tenuous at best. Elimination of a pension plan would not necessarily produce an increase in current employee compensation. The vesting provisions generally present in pension plans tend to promote personnel stability by providing an incentive for employees to remain with their employer. ${ }^{130}$ As the Court said in Alabama Power, "By rewarding lengthy service, a plan may reduce employee turnover and training costs and help an employer secure the benefits of a stable work force."131 One of the benefits of personnel stability may be increased employee productivity, and it is conceivable that the reduction in training costs and higher productivity might actually "pay" for some pension plans.

125431 U.S. 581 (1977).

${ }^{128} 38$ U.S.C. $\$ 2021$ (Supp. V 1975).

127431 U.S. at 593.

12x Id. at 592.

129 Id. at 593.

${ }^{130}$ See, e.g., Litwicki v. PPG Industries, Inc., 386 F. Supp. 296, 305 (W.D. Pa. 1973), aff'd, $505 \mathrm{~F} .2 \mathrm{~d} 189$ (3d Cir. 1974) ("the primary purpose of the retirement benefit is to promote personnel stability by giving the employee an incentive to remain with the company").

131431 U.S. at $592 \mathrm{n} .16$. The magnitude of the turnover problem is suggested by one labor economist's estimate, based on Bureau of Labor statistics, "that upwards of 10 million people, or one-sixth of all wage and salary earners, change jobs in a typical year." L. REYNOLDs, LABOR Economics AND LABOR RELATIONS 60 (5th ed. 1970) (footnote omitted). The expense to employers is manifold:

Costs of labor turnover to the employer are both direct and indirect. There are the bookkeeping costs involved in taking persons on and off the payroll, an item which has increased with the extra records and reporting entailed in the government social security problems. The greatest expense is that incurred in the interviewing, selection, and breaking in of new workers. . . . During this period of training and breaking in, the new employee's output is naturally low, causing an increase in unit labor costs.

F. Peterson, Survey of LABOR EConomics 207-08 (rev. ed. 1951). 
Even if elimination of pension plans would free some resources, it is not clear, especially in view of the tax advantages of pension arrangements, ${ }^{132}$ that those resources would necessarily be passed on to employees in the form of increased wages. ${ }^{133}$

Thus, the Daniel court's view of the relationship between employee services and the employer's contributions is too facile. The nature of the pension exchange is far more complex. The "investment" made by any individual employee is his remaining on the particular job beyond the time he would otherwise have departed. This "investment"-the employee's opportunity cost-does not, however, translate into funds contributed by the employer.

\section{B. Profits and Profit Motivation}

The absence of any tangible employee investment makes it difficult to find an element of profit in the pension transaction. The employee's expected profit would be the difference between the employee's investment or cost of participation in the pension plan and the pension benefit he expects to receive. ${ }^{134}$ The Daniel court found the profit element in the difference between the expected benefits and the "contributions made by the employer on the employee's behalf." ${ }^{135}$ However, this analysis does not withstand scrutiny. The court erred in equating the employee's cost with the employer's contribution on the employee's "behalf." In a noncontributory, defined benefit pension plan the employee has no right whatever to the contributions made on his behalf. Prior to vesting the employee has neither a right to the contributions made on his behalf nor a right to pension benefits. ${ }^{138}$ Subsequent to vesting the em-

132 See I.R.C. $\S 404$; Treas. Reg. $\$ 1.402(a)-1$ (a)(1)(i), T.D. 6887, 1966-2 C.B. 129. The primary advantage of receiving compensation in the form of pension benefits is tax deferral. Moreover, if the pension plan "qualifies" under the Internal Revenue Code, the employer can deduct his contributions to the pension fund as an ordinary business expense. See generally 4A J. Mertens, The Law of Federal Income Taxation ch. 25B (rev. ed. 1972).

133 It is possible that dropping a pension demand would yield no additional salary at all-for example, where an employer wished to match the prevailing salary and benefit levels, and was unwilling to vary the composition of his wage-benefit package because he believed that such action would impair business relationships or make it more difficult to attract new employees.

Brief of Secretary of Labor, Amicus Curiae at 17, Daniel v. International Bhd. of Teamsters, 561 F.2d 1223 (7th Cir. 1977).

13 In United Housing Foundation, Inc. v. Forman, 421 U.S. 837, 852 (1975), the Supreme Court stated that "[b]y profits, the Court has meant either capital appreciation resulting from the development of the initial investment . . . or a participation in earnings resulting from the use of investors' funds."

iss 561 F.2d at 1234.

is See text at notes 103-124 supra. 
ployee does not acquire a right to contributions made on his behalf but rather an enforceable contractual right to promised pension benefits. ${ }^{137}$ The contributions by the employer do not represent the employee's costs but the employer's actuarially-determined cost of maintaining the pension plan. ${ }^{138}$ The employee's "investment" consists of the opportunity costs he incurs by remaining in the particular employment until his pension rights have vested. It is impossible to determine whether the expected benefits "exceed" the èmployee's opportunity costs, for the costs seem to defy quantification.

The motivation behind the employee's participation in a pension plan cannot be characterized as "expectation of profit." It may be said that the employee views the pension arrangement as favorable in that he values the possibility of a secure retirement income more highly than the opportunities he loses by remaining with his employer until vesting. But that preference is not a profit expectation within the meaning of the Supreme Court's investment contract cases. In United Housing Foundation, Inc. v. Forman, ${ }^{130}$ the Court stated that "[b]y profits, the Court has meant either capital appreciation resulting from the development of the initial investment . . . or a participation in earnings resulting from the use of investors' funds . . . . In such cases the investor is 'attracted solely by the prospects of a return' on his investment."140 The Forman Court labeled the theory that the mere favorability of an exchange supplies the profit element "an inappropriate theory of 'profits' that we cannot accept."141

The role of the profit expectation branch of the Howey test is crucial. The promise of profits supplies the powerful lure that the protections of the federal securities laws are designed to counteract. ${ }^{1+2}$ That lure is absent in the case of noncontributory, defined

${ }^{137}$ If the employee had a right to the contributions made on his behalf, then the pension plan would be a defined contribution pension plan rather than a defined benefit pension plan. See note 4 supra.

13* Attribution of contributions to employees in an economic sense rests upon a fundamental confusion. Specifically, it confuses a method of funding an obligation with the obligation itself. One commentator has noted this problem:

Any consideration of employee . . . benefit plans must make a sharp distinction between two factual levels. The first is the level of the individual plan and the relation to it of the employee participants. The second is the level of the investment medium which is used to fund the individual plan and the relation to that medium of the employer who sets up the plan and chooses the investing medium.

Mundheim \& Henderson, supra note 9, at 837.

139421 U.S. 837 (1975).

Ho Id. at 852 .

sil Id. at 855 .

142 In Howey, the Court emphasized that investors were "attracted by the expectation of substantial profits." 328 U.S. 293 , 296 (1946). 
benefit pension plans. In the final analysis, noncontributory, defined benefit pension plans-like cooperative housing arrangements ${ }^{133}$-are not rivals to mutual funds, variable annuities, withdrawable capital shares or any of the other "countless and variable schemes devised by those who seek the use of money of others on the promise of profits."ist

\section{Why Securities Regulation?}

The preceding section has argued that interests in noncontributory, defined benefit plans are not "investment contracts" under the Supreme Court's tests. Even so, employees who participate in a plan acquire a reliance interest over years of service, an interest that certainly deserves protection. But analysis of the risks associated with noncontributory plans, and of the congressional response to the need for protection against those risks, suggests that securities law protection is unnecessary and perhaps obstructive of congressional policy goals.

Pension plans have been subject to federal regulation for some time.$^{145}$ Given the scope of protection provided by ERISA, and the general understanding, at the time of its enactment, that the securities laws did not apply to interests in noncontributory plans, ${ }^{146}$ it could be argued that ERISA preempts the field. Nevertheless, proponents of the view that pension interests are securities assert that securities law disclosure is a necessary complement to ERISA's requirements. ${ }^{1.7}$

The federal securities laws would require disclosure of all material facts, including "risk of loss," 148 prior to the investment decision. By contrast, "ERISA disclosure limits itself to the plan provisions without a particularizing of how or how likely benefits may be lost," "19 and disclosure may be made as late as ninety days after the

143 See United Housing Foundation, Inc. v. Forman, 421 U.S. 837 (1975).

il SEC v. W.J. Howey Co., 328 U.S. 293, 298 (1946). See M. Bernstein, The Future of Private Pensions 9 (1964). ("Of course, the basic purpose of private pension plans is to provide income to those who have worked and who retire from choice or necessity. Undoubtedly most unions and employers sincerely desire that employees have fully adequate retirement income.").

is See generally Chadwick \& Foster, Federal Regulation of Retirement Plans: The Quest for Parity, 28 Vand. L. Rev. 641 (1975).

111 See text and notes at notes 37-42 supra, and note 161 infra.

17 See, e.g., Daniel v. International Bhd. of Teamsters, 561 F.2d 1223, 1248 (7th Cir. 1977), petition for cert. filed, 46 U.S.L.W. 3374 (U.S. Dec. 6, 1977). (Nos. 77-753 \& 77-754).

iss Id.

to Id. 
employee becomes a plan participant. ${ }^{150}$ Thus, it is argued, application of the securities laws would complement ERISA by requiring "full disclosure of the terms of the plan and risks associated with it" at the time an employee is offered a job. ${ }^{151}$

The argument that securities law protection is needed because of gaps in ERISA disclosure is not persuasive. For one thing, the inequitable conduct usually connected with noncontributory pensions is not fraudulent inducement to take employment, but fraudulent or unfair inducement to remain on the job, a wrong that preemployment "disclosure" will not remedy. ${ }^{122}$ Secondly, if disclosure is really desirable it would seem that the registration provisions-the disclosure provisions of the securities acts-should apply. But Congress exempted the bulk of private pensions from registration in $1970,{ }^{153}$ and the SEC maintains, as did the Daniel court, that registration is not required. ${ }^{154}$

Moreover, securities laws disclosure is an inappropriate means of protecting employees against the kinds of risks associated with noncontributory, defined benefit pension plans. Noncontributory pension plans involve two sorts of risks. One risk is that the employee will fail to satisfy the plan's vesting requirements. The other risk is that the fund will prove inadequate to provide the contractedfor benefits. ERISA deals with both sorts of risk, not by requiring complete disclosure, but by substantive regulation. ${ }^{155}$ Implicit in ERISA is a legislative judgment that disclosure is an inadequate remedy for the ills of the private pension system.

Included in the second sort of risk-the risk that the pension fund will prove insufficient to provide the contracted-for benefits-is a risk that might be called an "investment risk." It is the risk that the fund will be inadequate as a result of poor investment decisions by plan trustees. But this "investment risk" is far differ-

150 ERISA $\S 104(b)(1), 29$ U.S.C. $\S 1024(b)$ (1) (Supp. V 1975).

151 Brief for the Institute for Public Interest Representation, Amicus Curiae at 5, Daniel v. International Bhd. of Teamsters, 561 F.2d 1223 (7th Cir. 1977),

152 According to SEC Chairman Williams, testifying before the Senate Human Resources Subcommittee on Labor, ERISA's requirement of disclosure 90 days after employment in the form of a summary plan description would be just as adequate as preemployment notification with respect to investment in a plan. 159 PENS. REP. (BNA) A-16 (Oct. 17, 1977).

153 The 1970 Investment Company Amendments Act, Pub. L. No. 91-547, 84 Stat. 1413 (1970) (codified in scattered subsections of 15 U.S.C. \$ 80a-1 (1970)), specifically exempts most pension interests from registration. One estimate is that $96 \%$ of all pension plans are now exempt from registration. See Daniel v. International Bhd. of Teamsters, 561 F.2d 1223, 1250 n.61 (7th Cir. 1977), petition for cert. filed, 46 U.S.L.W. 3374 (U.S. Dec. 6, 1977) (Nos. 77-753 \& 77-754).

134 See note 108 supra.

${ }^{15 s}$ See text and note at note 159 infra. 
ent from that associated with the typical securities transaction. In the case of the pension plan, the "investment risk" falls principally upon the employer: the employer must increase contributions to the fund in years subsequent to poor investment performance in order to offset the poor performance and keep the fund fully "funded." Moreover, the "investment risk" associated with the pension plan is not uncontrolled, as it typically is in the case of mutual funds, variable annuities, and other similar sorts of securities transactions. The "investment risk" of the pension plan is controllable to the extent that investment performance is accurately taken into account by the actuarial assumptions and calculations employed in funding the pension. In fact, if actuarial science operated with certainty, there would be no investment risk involved in the noncontributory, defined benefit pension plan-at least from the standpoint of the employee. This suggests that it is not disclosure of "investment risks" that is needed but rather regulation of funding and actuarial assumptions, and this is exactly what the Internal Revenue Code and ERISA do. ${ }^{158}$

The major risk involved-and that with which the Daniel case was actually concerned-is the risk that the participant will inadvertently fail to satisfy a prerequisite to vesting. ${ }^{157}$ As the Senate Report accompanying ERISA noted, "In almost every instance, participants lose their benefits not because of some violation of federal law, but rather because of the manner in which the plan is executed with respect to its contractual requirements of vesting or funding." 158 ERISA attempts to remedy this problem through minimum vesting standards and rules regulating loss of rights resulting from a break in employee service..$^{158}$

iss See I.R.C. $\S \S 412,4971$; ERISA $\S \S 301-305,29$ U.S.C. $\S \S 1081-1085$ (Supp. V 1975) (funding requirements); I.R.C. $\S 412$ (c)(3); ERISA $\S 302(c)(3), 29$ U.S.C. $\S 1082$ (c)(3) (Supp. $\mathrm{V}$ 1975) (actuarial assumptions).

isz See W. Greenough \& F. King, supra note 1, at 155.

is" S. REP. No. 127, 93d Cong., 1st Sess. 203 (1973).

13) See ERISA § 203(a)(2), 29 U.S.C. $\$ 1053(a)(2)$ (Supp. V 1975) (minimum vesting standards); ERISA $\S 203(b)(3), 29$ U.S.C. $\S 1053(b)(3)$ (Supp. V 1975) (break-in-service rules).

As explained in the Secretary of Labor's amicus brief in Daniel:

A "break in service" rule that cuts off eligibility for pension benefits because of a few months' involuntary lay-off in the midst of a 22 year period of otherwise continuous covered service is not only arbitrary; it is unfair in the extreme, shocking to the conscience. Before the passage of ERISA, when employee benefit plans were not required to meet any substantive minimum standards, examples of similar inequities were legion. The prevalence of such unjust results was one of the primary motivating forces leading to adoption of the minimum standards for plan participation, vesting and benefit accrual. 
Although securities laws protection of interests covered by ERISA appears unnecessary, ERISA does not protect those who, like the plaintiff in Daniel, lost their pension rights prior to the effective date of the Act. If ERISA's regulations applied retroactively, such employees could earn reinstatement of their pension rights under the Act's break-in-service rules, and the need for a securities antifraud remedy would be less urgent. But the nonretroactivity of ERISA is not accidental. The decision to make the Act nonretroactive was the product of a conscious compromise between remedial purpose and the desire to avoid disrupting existing pension plans. ${ }^{160}$ The kind of liability envisioned by the Daniel complaint could seriously disrupt existing plans. It would be retroactive in the sense that the liability is premised on conduct that was not previously believed to be violative of the securities laws ${ }^{161}$ and that the employer is now powerless to undo.

Moreover, the theory of the Daniel complaint, though fashioned primarily to meet a particular remedial lacuna, cannot logically be limited to cases in which employees lost their rights prior to the effective date of ERISA. Employees protected by ERISA's minimum vesting standards and break-in-service rules might nevertheless find a securities cause of action an attractive alternative. The availability of such actions would require of employers disclosures the scope of which is unknown. In response to queries concerning the kinds of disclosure that would be required in order to avoid anti-

Brief of the Secretary of Labor, Amicus Curiae at 20-21, Daniel v. International Bhd. of Teamsters, 561 F.2d 1223 (7th Cir. 1977).

${ }^{160}$ Congressman Thompson of New Jersey explained on the floor of the House:

I am proud to say that I believe we have reconciled the competing interests of participants and pension plan sponsors in a way that speeds the protection of the new standards without creating undue financial dislocation or immediate disruption of existing pension plans. By way of explanation, I would draw the attention of my colleagues to the provisions dealing with the effective dates for the vesting, participation and eligibility provisions contained in part 2 of title I. Under the conference substitute the provisions with respect to participation and vesting will apply to new pension plans in plan years beginning after the date of enactment of the conference report. For pension plans in existence on January 1, 1974, the general effective date of the participation and vesting provisions is to be plan years beginning after December 31,1975 .

120 Cong. Rec. 29195 (1974).

${ }^{16 t}$ At no time during the period of ERISA's development was it ever stated to me or, to the best of my knowledge, to any other member of Congress that the Securities Acts' antifraud provisions applied to noncontributory, involuntary pension plans. . . .

The lack of notice is very important because, given the delicate balance Congress sought to strike in ERISA, notice that the antifraud provisions were applicable to a fact situation such as that in Daniel certainly would have been a matter worthy of legislative consideration .... .

Letter from Senator Williams to SEC Chairman Williams (Dec. 13, 1977), reprinted in 168 Pens. Rep. (BNA) R-19, R-20 (Dec. 19, 1977). 
fraud liability, the SEC has said only that it is essentially a "caseby-case" matter. ${ }^{162}$ To impose disclosure duties in addition to those imposed by ERISA seems plainly contrary to Congress's intent to minimize the burdens on the private pension system. ${ }^{163}$ As Congressman Ullman stated:

I want to emphasize that these new [ERISA] requirements have been carefully designed to provide adequate protection for employees and at the same time, provide a favorable setting for the growth and development of private pension plans. It is axiomatic to anyone who has worked for any time in this area that pension plans cannot be expected to develop if costs are made overly burdensome, particularly for employers who generally foot most of the bill. This would be self-defeating and would be unfavorable rather than helpful to the employees for whose benefit this legislation [ERISA] is designed. ${ }^{164}$

In ERISA Congress has carefully balanced the costs and benefits of participant protection. The courts should not upset that balance by applying the federal securities laws to transactions not properly within their scope. ${ }^{165}$

\section{CONCLUSION}

This comment has argued that employee interests in noncontributory, defined benefit private pension plans are not "securities" subject to the federal securities laws. Such interests are not investment contracts under the Howey "investment contract" test be-

1162 "The listing of various items of information to be disclosed to plan participants... is part of the realm of registration requirements of the federal securities laws. There is, and can be, no definite list of items which must be disclosed under the antifraud provisions." Memorandum from the SEC Office of General Counsel to SEC Chairman Williams (Dec. 7, 1977), reprinted in 168 PENS. REP. (BNA) R-17, R-18 (Dec. 19, 1977). The memorandum states that the touchstone under the antifraud provisions is "the concept of materiality" and "materiality must be judged on a case-by-case basis." Id.

is Senator Williams, Chairman of the Senate Committee on Labor and Public Welfare, Chairman of the Subcommittee on Labor, and co-sponsor of ERISA, has expressed concern that the Daniel decision might result in upsetting the "delicate balance Congress sought to strike in ERISA." Letter from Senator Williams to SEC Chairman Williams, supra note 160, at R-20. In the Foreword to the Legislative History of ERISA Senator Williams wrote: "The new rules [of ERISA] reflect a careful balance of incentives and controls designed by Congress to improve the equitable character of private plans while encouraging their future growth and development." I Senate Comm. on Labor and Public Welfare, 94th Cong., 2d Sess., Legislative History of the Employee Retirement Income Security Act of 1974, at III (1976).

M 120 CONG. REC. 29198 (1974).

us "[N]ot every plan generating allegations of fraud is a violation of federal securities law." Lino v. City Investing Co., 487 F.2d 689, 695 (3d Cir. 1973). 
cause of the difficulty in identifying a measurable employee investment and because of the difficulty in identifying the requisite profit in the pension transaction. These factors, buttressed by policy considerations, indicate that the extension of federal securities law protection to noncontributory, defined benefit pension interests is unwarranted.

Robert V. Gunderson, Jr. 